1989

\title{
Petit Treason in Eighteenth Century England: Women's Inequality Before the Law
}

Shelley A. M. Gavigan

Osgoode Hall Law School of York University, sgavigan@osgoode.yorku.ca

Source Publication:

Canadian Journal of Women and the Law. Volume 3, Number 2 (1989-1990), p. 335-374.

Follow this and additional works at: https://digitalcommons.osgoode.yorku.ca/scholarly_works

\section{Recommended Citation}

Gavigan, Shelley A. M. "Petit Treason in Eighteenth Century England: Women's Inequality Before the Law." Canadian Journal of Women and the Law 3.2 (1989-1990): 335-374.

This Article is brought to you for free and open access by the Faculty Scholarship at Osgoode Digital Commons. It has been accepted for inclusion in Articles \& Book Chapters by an authorized administrator of Osgoode Digital Commons. 
Osgoode Legal Studies Research Paper No. 16

Vol. 13/ Issue. 4/ (2017)

\title{
Petit Treason in Eighteenth Century England: Women's Inequality Before the Law
}

\author{
Canadian Journal of Women and the Law, Vol. 3(2), 1989.
}

Shelly A. M. Gavigan

\begin{abstract}
:
This article examines the English law of petit treason (murder of a husband by his wife or a master by a servant or a religious superior by a religious inferior) and its implications for married women charged with murdering their husbands. From 1351 - 1828, a woman accused of killing her husband was liable to be indicted not for wilful murder but for the aggravated offence of petit treason and, until 1790, she faced public execution by burning if convicted. Relying on eighteenth century legal treatises, reported cases, press accounts of women's trials, and secondary sources, the author discusses the cases of several women tried for petit treason. The general legal position of married women in eighteenth century England is also examined, and it is argued that the law of petit treason was a logical extension and consistent expression of women's unequal position in marriage and subordinate status more generally. With the elimination of the aggravated penalty of burning at the stake, and the ultimate repeal of petit treason altogether, married women who killed their husbands achieved a measure of formal equality previously denied them. However, the author argues the significance of petit treason cannot be explained adequately by a trans-historical concept of patriarchy or male dominance. Analysis of both the form of law, and the form of patriarchal relations enforced and reinforced, is identified as of paramount importance.
\end{abstract}

\author{
Author(s): \\ Shelly A. M. Gavigan \\ Osgoode Hall Law School, York University \\ E: sgavigan@osgoode.yorku.ca
}




\title{
, Petit Treason in Eighteenth Century England: Women's Inequality Before the Law
}

Q 1981, 1989 by Shelley A.M. Gavigan

\begin{abstract}
Cet article étudie la loi anglaise de "petit treason" (meurtre d'un mari par sa femme, d'un maître par son domestique ou d'un religieux par un religieux qui lui est subordonné) et ses implications pour les femmes mariées accusées d'avoir tué leurs maris. De 1351 à 1828, une femme accusée d'avoir tuée son mari pouvait être inculpée non de meutre prémédité mais de "petit treason." Jusqu'en 1790, elle était menacée d'exécution publique sur le bûcher si elle était trouvée coupable. L'auteure traite du cas de plusieurs femmes accusées de "petit treason" en s'appuyant sur des traités de droit du 18 e siècle, des causes publiées dans les recueils de jurisprudence, des comptes rendus de procès de femmes faits par la presse et des sources secondaires. $L a$ situation juridique générale des femmes mariées en Angleterre au 18 e siècle est également étudiée. On affirme que la loi de "petit treason" constituait une extension et une illustration logiques de la situation inégale de la femme mariée et plus généralement de son statut de subordonnée. Grâce à l'élimination de la peine de mort sur le bûcher et l'abrogation définitive et complète de la loi de petit treason," les femmes mariées ayant tué leurs maris ont obtenu une part d'égalité formelle qui leur était avant refusée. Toutefois, l'auteure affirme que la signification de la loi de "petit treason" ne peut être expliquée adéquatement par un concept trans-historique de patriarcat ou de domination masculine. Une analyse de la forme de la loi et de la forme des relations patriarcales, en vigueur et appliquées, est jugée d'importance capitale.
\end{abstract}

This article examines the English law of petit treason (murder of a husband by his wife or a master by a servant or a religious superior by a religious inferior) and its implications for married women charged with murdering their husbands. From 1351 - 1828, a woman accused of killing her husband was liable to be indicted not for wilful murder but for the aggravated offence of petit treason and, until 1790, she faced public execution by burning if convicted. Relying on eighteenth century legal treatises, reported cases, press accounts of women's trials, and secondary sources, the author discusses the cases of several women tried for petit treason. The general legal 
position of married women in eighteenth century England is also examined, and it is argued that the law of petit treason was a logical extension and consistent expression of women's unequal position in marriage and subordinate status more generally. With the elimination of the aggravated penalty of burning at the stake, and the ultimate repeal of petit treason altogether, married women who killed their husbands achieved a measure of formal equality previously denied them. However, the author argues that the significance of petit treason cannot be explained adequately by a trans-historical concept of patriarchy or male dominance. Analysis of both the form of law, and the form of patriarchal relations enforced and reinforced, is identified as of paramount importance.

\section{Introduction}

The exemption of Women from several Pains and Penalties by our Laws, is made an objection to them. This favour is an insult and supposes Women mere nothings, and votes them dead in law. They shall suffer for Treason committed with their Husbands; this is a Grievance: They shall not suffer in some other cases: this is a Grievance also. The Husband is alone liable to Imprisonment for Debt, even of his Wife's contracting before or after Marriage, and for neither was any remedy; his Estate shall pay her Debts, while her jointure and Settlement are untouch'd, and out of the Question: Yet these are no Privileges; they are affronts to the Sex. Mercy on Me! What would the Women have?

...the house of every one is to him as his castle. ${ }^{2}$

The law of petit treason offers both an answer to the seemingly timeless lament of the bewildered English man who duthored the first quotation and a new meaning to the axiom that a man's home is his castle. From 1351 until 1790, English law provided that a woman who murdered her husband was liable to be convicted of "petit treason" and to suffer the fate of female traitors: to be burned at the stake. The official justification for the offence was the duty of subjection and obedience owed by English wives to their husbands; the penalty was defended in the name of the natural modesty of the female sex - it was better to be burned at the stake than to be drawn and quartered, the official penalty for treason.

An earlier version of this paper was presented at the Sociology of Law session of the Annual Meeting of the Canadian Sociology and Anthropology Association, University of British Columbia, Vancouver, June 1983. I wish to thank Douglas Hay, Judy Fudge, Judy Deverell, Elizabeth Pickett, and the anonymous reviewers for the Canadian Journal of Women and the Law for their very helpful comments and suggestions on this paper as it progressed. I am especially grateful to Susan Boyd for
her insightful and careful editing, and to Suzanne White for her superb technical assistance. I am responsible for any weaknesses that remain

1. Anon., The Gentleman's Magazine 6 (November, 1737): 649.

2. Semayne's Case (1604), 5 Co. Rep. 9la, 77 English Reports 194.
This article presents not a complete social history of petit treason but rather a preliminary examination of its legal history. ${ }^{3}$ I offer this piece of women's legal history as a tontribution to the larger feminist project of developing a historically informed understanding of the complexity of women's subordination in different contexts, and the nature of law's contribution thereto. Petit treason is not simply illustrative of yet another discriminatory legal practice,${ }^{4}$ nor, in my view, can it be adequately explained in more general terms by a transhistorical concept of male dominance ${ }^{5}$ or patriarchy. ${ }^{6}$ Nor do I think that "[t]he story of women who kill is the story of women," as American feminist historian Ann Jones asserted in her early groundbreaking work, Women Who Kill. ${ }^{7}$ This is not to deny that Ann Jones' work is an important contribution to the research in various disciplines which tells us that women who kill, kill their intimates (their children, husbands, and lovers) ${ }^{8}$ in their homes. ${ }^{9}$

Married women in eighteenth century England experienced "patriarchy" most profoundly in the unmediated dominion of their husbands. They were unequal at law in every sense of the word, and had no real basis upon which to assert a claim for equality with men, most of whom had few formal rights themselves. The law of petit treason did not, however, affect only married women. Servants (or slaves in the American colonies) who killed their masters were also caught by the aggravated offence and liable to the higher penalty. Ann Jones found that black women in the American colonies were more likely to be convicted of petit treason for the murder of masters or mistresses than for the murder of their husbands. ${ }^{10}$

In this article, particular emphasis is laid on the effects of this statutory offence upon wives accused of murdering their husbands. This is not to suggest that the implications of this offence for servants were not equally onerous, and reflective of an older social, economic, and legal order based upon feudal relations and practices which became outmoded with the development of

3. The only other study of petit treason I have found is Ruth Campbell, "Sentence of Death by Burning for Women," Journal of Legal History 5 (1984): 44-59. Campbell discusses, among others, the cases of Catherine Hayes, Mary Fawson, Ann Williams, and Margery Beddingfield in 18 th century Surrey and Sussex. John Beattie discusses petit treason in relation to the case of three women accused of murdering their husbands (two of whom were convicted and sentenced to be burned to death). See J.M. Beattie, Crime and the Courts in England 1660-1800 (Princeton: Princeton University Press, 1986), 100-101.

4. Campbell, "Sentence," 53-4, argues that "this whole area smacks of discrimination.... [t] the law in this area was a one-sided exercise, a handbook of authority - of the Crown, the Church, the landed, the male."

5. See, e.g., Catharine A. MacKinnon, "Feminism, Marxism, Method, and the State: An Agenda for Theory," Signs 7 (1982): 515-544 and "Feminism, Marxism, and the State: Toward Feminis Jurisprudence," Signs 8 (1983) 4: 635-658.

6. See, e.g., Janet Rifkin, "Toward a Theory of Law and Patriarchy," Harvard Women's Law Journal

7. Ann Jones, Women Who Kill (New York: Holt, Rinehart \& Winston, 1980), xvi.
8. See, e.g., Marvin Wolfgang, Patterns of Criminal Homicide (Philadelphia: University of Philadelphia Press, 1958); Otto Pollak, The Criminality of Women (New York: A.S. Barnes \& Co. André Lachance "Women and Crime in Canada, Journal of Social History 8 (1974-75): 80-116 in Crime and Criminal Justice in Europe and Canada, ed. Louis A. Knalfa (Waterloo: Wilfred Laurier University Press, 1981), 110; Beattie, Crime and the Courts, 106.

9. Wolfgang, Patterns of Criminal Homicide, Lachance, "Women and Crime."

10. Jones, Women Who Kill, 39-42. 
capitalist social relations. The specific melding of class and gender relations in this law rendered the distinction between wives and servants in relation to the husband who headed the household essentially a nominal one. The law of petit treason thus both reflected and reinforced social and economic relations of gender and class that were feudal in nature. Social relations, and this law which structured them, were hierarchical in their form and in their essence. The domination of women by men, however humble their social class, derived from their position as heads of households, as patriarchs, as kings of their privat castles.

Women who kill their husbands are no longer indicted for the aggravated offence of petit treason and burned at the stake as traitors if convicted. In the case of a woman or man who kills her/his spouse, Anglo-Canadian and Ameri case are premised upon the principle of formal equality given the substantive inequality women in these societies? women in these societies? An examination of the profoundly brutal and iniquitous law of petit treason with respect to women who killed their husbands helps us to develop an understanding of the relationship of women and law in the current context, not because the legal position of women today is the same, but rather and more accurately because it has changed. To assert that the subordination of women today may not be equated with the lives and experiences of women of eighteenth century England is not to deny the patriarchal features of both. What needs to be examined and understood however, are the different forms of patriarchal domination in these different historical contexts, and for our purposes here, the nature of the contribution of the state and the law to those forms. As Michèle Barrett has argued:

What we need to analyse are precisely the mechanisms by which women's oppression is secured in different contexts, since only then can we confront the problem of how to change it.11

This is no small task, particularly given the apparently transhistorical nature of women's oppression.

To observe that women have not achieved real equality despite successful (albeit uneven, incomplete, and fragile) struggles for formal equality need not lead one to conclude that formal equality is merely a sham. On the contrary, as one feminist of the second wave has argued, formal equality is at the very least "itself a certain progress, which can help to make possible is at the very least "itself a certain progress, which can help to make possible a further advance."12 While it is imperative that we look beyond the law to the substantive economic and social inequalities which continue to exist, it is nonetheless important to remember the moment and the conditions which facilitated, perhaps required the restructuring of social and economic relations upon a formally equal footing.

11. Michèle Barrett, Women's Oppression Today (London: Verso, 1980), 250.

13. See for

work has contributed greatly to the revitalization, an early Soviet jurist (the recovery of whose
For some feminists, the form of law is not problematic, but rather is always and everywhere the ultimate symbol, if not instrument, of male authority. In my view, this perspective seriously limits one's ability to analyse and understand the different forms and contexts of law and its relationship to the subordination women. I share E.P. Thompson's perspective in this respect:

If we suppose that law is no more than a mystifying and pompous way in which class [or "male"] power is registered, then we need not waste our labour in studying its forms. One Act would be much the same as another and all, from the standpoint of the ruled would be Black. It is because law matters that we have bothered with this story at all. ${ }^{14}$

The contradiction between formal equality and substantive inequality of women in the current context simply cannot be dismissed as an ideological trick of patriarchy or capitalism, but rather must be analysed.

This concern with form, and formal equality before the law, must always acknowledge the limitations of changes in the legal form; as Juliet Mitchell has observed:

[b]oth the history of feminism and the ideology of equality in general and for women in particular offer a monument to the law of uneven
development. ${ }^{15}$

Nevertheless, Philip Corrigan and Derek Sayer have argued:

Bourgeois right, whether de l'homme or du citoyen, is of its very essence a pure right, a right defined independently of the particulars of empirical circumstance or the facts of real difference. Of course, such formal emphasis on equality before the law can and does co-exist with substantive clustering and grouping which facilitates systematic inequality: at any given point in time classes) of people-lunatics, criminals, blacks, Roman Catholics, women, those who do not own real property, and their ilk - have always been excluded from the full rights of (sane law abiding always Anglo-Saxon, protestant, male and propertied) 'Man'. But these are there can be no general theory of law which is transhistorical, and that only with the advent of complete distinctness in social relations." Evgeny B. Pashukanis, Law and Marxism (London Ink Links, 1978), 58

15. Juliet Mitchell, "Whigs and Hunters (Middlesex: Penguin Books, 1977), 267-68. and Ann Oakley (Middlesex. Penguin," in The Rights and Wrongs of Women, eds. Juliet Mitchell 
precisely, exclusions, and there is - in more than a figurative sense world of difference between this and, say, the feudal state of affairs. ${ }^{16}$

The substantive inequality of women in feudal society, developing capitalist society, and in advanced capitalist society cannot be denied. There is a certain "transhistoricity" to the oppression of women. But the forms of that oppression have changed, as have the forms through which it can be resisted and challenged.

Finally, there is one respect in which some feminist critiques of law as an instrument of male authority are most problematic. If we conceptualize patriarchy or male dominance as determinative of women's lives, we leave no room for an appreciation of the nature and significance of women's agency and resistance. In many ways, this problem is analogous to the "Achilles heel" of traditional legal scholarship in that the analysis of the law alone may not tell us much, if anything, about the lived experience of the "ruled." 17 Thus even in the context of gross social, sexual, and economic inequality of women, the apparent may not necessarily be determinative or indicative of the essence. ${ }^{18} \mathrm{We}$ must be prepared to identify the form of male domination expressed and enforced in the law of petit treason; we must also attempt to identify shifts and contradictions in attitudes, ideas, practices, and conditions at different moments over time. The law of petit treason and the fate of the convicted women scarcely offer us a picture of an idyllic period in women's history. But it is with E.P. Thompson's urging of "second sight" that I turn first to an examination of the general legal position of married women in the eighteenth century, and then to an examination of the law of petit treason.

16. Philip Corrigan and Derek Sayer, "How the Law Rules: Variations on Some Themes in Karl Marx," in Law, State and Society, eds. Bob Fryer, et al. (London: Croom Helm, 1981), 32. See also Mitchell, Woman's Estate, and Pashukanis, Law and Marxism.
Thompson, Whigs and Hunters; Minow, "Forming Underneath Everything that Grows: Toward

a History of Family Law," Wisconsin Law Review (1985): 819-98.

18. In this respect, E.P. Thompson's analysis of the practice of wife-selling in rural eighteenth century England is interesting. This practice, by which husbands would bring their wives to market and sell them to a buyer was denounced as immoral by religious and politica authorities, on the face of it, who could deny such a charge? And yet, E.P. Thompson has un wife's lover as the prearranged buyer) at

At first sight we appear to have a form reminiscent of negative bridewealth, or perhaps mere chattel purchase. . .Here is the ne plus ultra of a dominant male order But at second sight, when we look through the form to the actual relations expressed within it, it appears differently. The ritual (whatever its origin and manifest symbolism) has been adapted to new purposes in which it regulates an exchange of parties by mutual consent. But although we find with the ritual greater evidence of sexual equality than we had at first expected to find, the ritual itself remains one of feminine [sic] subordination. Wives did not, except in very

E.P. Thompson, "Folklore, Anthropology and Social History," A Studies in Labour Pamphlet (Brighton: John Noyce, 1979), 9. I am indebted to Gordon West for first drawing this text to my attention. See also Samuel Pyeatt Menefee, Wives for Sale: An Ethnographic Study of British Popular Divorce (Oxford: Basil Blackwell, 1981) and Katherine O'Donovan, "Wife Sale and Desertion as Alternatives to Judicial Marriage Dissolution," in The Resolution of Family Conflict: Comparative Legal Perspectives, eds. John M. Eekelaar and Sanford N. Katz (Toronto Butterworths, 1984), 41 .

\section{The Legal Position of Married Women in Eighteenth Century England}

The law of petit treason, as it applied to women who killed their husbands, was both a logical extension and a consistent expression of the general position of married women at law. A married woman was described by the phrase feme covert which reflected the fundamental principle that "by virtue of the marriage a husband and wife became one person in law" 19 That "one" of course was the husband, "the fittest and ablest to provide for and govern the family." ${ }^{20}$ Montague Lush, in his work on marriage law, cited Bracton as the author of the proposition that "the husband by law hath power and dominion over his wife: and may beat her, but not in a violent or cruel manner" 21

John Beattie suggests that although this right had been challenged in the courts in the seventeenth century, it was still thought to exist in the eighteenth century. ${ }^{22}$ However, in his more recent work Beattie also argues that:

...the legitimacy of [a husband] imposing his will by physical means was to some extent undermined by a growing hostility toward excessive

violence and the vicious beating of wives, children, and servants. ${ }^{23}$

In what appears to have been the first "women and the law" handbook for married women, the anonymous author explained this historical legal right of husbands, and advised women of their own rights in this respect:

And though our Law makes the Woman subject to the Husband, yet he may not beat her, but she may pray the Peace against him; and he shall find surety that he shall neither do nor procure to be done, any Bodily Damage, otherwise than appertains to the Office of a Husband, and for lawful Correction. ${ }^{24}$

A wife had a duty of consortium: a husband was "entitled to enjoy the society of his wife." 25 To ensure this right, the wife was deemed to be under the guardianship of her husband and he had a corresponding duty "for the sake of both, to protect her from the danger of unrestrained intercourse in the world."26 If a wife left her husband without his consent, and lived in an adulterous relationship, she lost her dower. ${ }^{27}$ If she simply left him, again without his

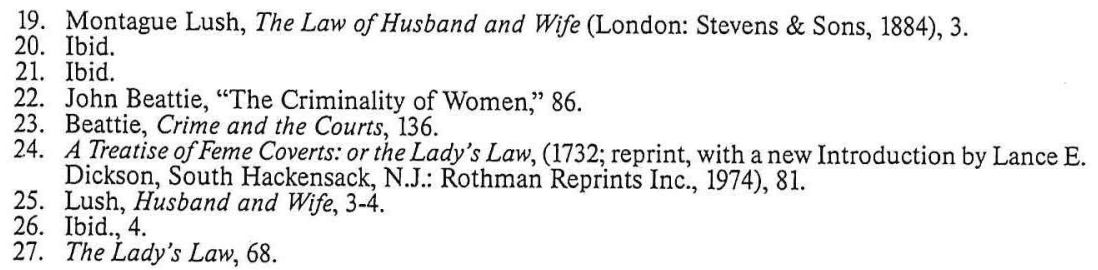


consent, he could prohibit persons from "trusting her," and anyone who had notice could not collect from him for bills she incurred:

... if she runs away from her Husband, then as soon as such Separation is Notorious, whoever trusts her doth it at his peril, and the Husband is not liable unless he take her again. ${ }^{28}$

The case of one woman who had attempted to live apart from her husband on account of his cruel (though apparently not violent) treatment was the subject of considerable discussion in The Gentleman's Magazine in 1735: the woman had sought refuge in the home of her brother, a cleric, who went to her husband to intercede on her behalf:

But the Husband insisted upon his Right to controul [sic], it was an Invasion of his Prerogative Royal for his wife to expostulate, and in short he ordered her brother to send her home again, or keep her at his Peril. This ill success, flung her into a lingering fever of which she languished a fortnight, when her Husband came in Person, and demanded his Wife. ${ }^{29}$

The woman was forced to return to her husband's home, where he, "exasperated by her Complaint, treated her with greater Harshness,"30 and she died within a month. The correspondent, apparently a woman, lamented the fact that this other woman had been unable to obtain any redress because her husband had never "beaten her, nor threatened her Life, tho' he took all other means to break her heart." 31

The recitation of the facts of this case prompted the following reinterpretation by a second author of what had actually happened:

Words pas'd between her Spouse, as sometimes will happen; Madam fir'd, and said, she had Relations and Houses to go to: In short, she not only threaten'd, but march'd off, and being brought back, chose to die of Vexation, rather than do the least Service for her Husband. ${ }^{32}$

28. The Lady's Law, 91-92. That he had a right to "take her again" is illustrated by her husband's ill-fated attempt in Mary Sayer's case, The Trial of Richard Noble, Mary Sayer and Mary

29. The Gentleman's Magazine 5 (June, 1735): 284.

30. Ibid.

32. The Gentleman's Magazine 6 (November, 1736): 648-649. This author is the anonymous author earlier quoted in note 1.
In response to the complaint in the earlier article regarding the inequality inherent in a marriage contract which allowed one party to break it but not the other, the second author suggested that "[1]ewd Women do not deserve this Privilege, and chaste ones would not desire it." 33 On the subject of equality for women, he was likewise unmoved, being hardpressed to find even one instance in English history of "the Sacrifice of one Female Vanity to the Publick Good."34

The legal authorities of the eighteenth century similarly regarded the subordination of women in both public and private life as proceeding from a natural state of affairs. These men were beginning to be challenged in their perception of women not only by the women who led the food riots, ${ }^{35}$ but by a source close to their very bosom: women "of quality" began to agitate in their own often isolated way as well.

Women in eighteenth century England began to demand equality with men and in so doing challenged not only the assumption of women's inferiority as a sex, but the male privilege which flowed therefrom. Sophia insisted upon women's right to an education:

Men, by thinking us incapable of improving our intellects have entirely thrown us out of all the advantage of education; and thereby contributed as much as possible to make us the senseless creature they imagine us. ${ }^{36}$

Both Sophia and Mary Wollstonecraft, who wrote several years later, cited custom and prejudice which clouded reason as the real sources of women's assumed and ensured inferiority. ${ }^{37}$ Of the "pedestal" reserved for women Wollstonecraft said:

I lament that women are systematically degraded by receiving the trivial attentions which men think it manly to pay to the sex, when in fact, they are insultingly supporting their own superiority. It is not condescension to bow to an inferior

She argued against the "distinction of sex" in society, which she believed to be "the foundation of the weakness of character ascribed to woman" 39 She

33. Ibid., 649 .

35. E.P. Thompson, "The Moral Economy of the English Crowd," Past and Present 50 (1971):

6. Sophia, A Person of Quality, Woman Not Inferior to Man (1739; reprint, London: Brentham

7. Ibid., 6; Mary Wollstonecraft, Vindication of the Rights of Woman, edited with an Introduction by Miriam Brody Kramnick (1792; reprint, Middlesex: Penguin Books, 1982), 91

38. Wollstonecraft, ibid., 147. 
acknowledged that women would have to give up the "trivial attentions" paid to them by men if they wanted to obtain an equal place in society, but felt that this sacrifice would be a small price to pay.

Wollstonecraft did not have the support of a feminist movement to carry her message forward, and her relative isolation and provocative views made her a good target of "barely printable insults." 40 One commentator at her death in 1797 urged that:

[her life and words be read] with disgust by every female who has any pretensions to delicacy; with detestation by everyone attached to the interests of religion and morality, and with indignation by anyone who might feel any regard for the unhappy woman, whose frailties should have been buried in oblivion. ${ }^{41}$

In addition, feminist historian Sheila Rowbotham has argued convincingly that the protest of the early bourgeois feminists, such as Sophia and Mary Wollstonecraft, was unconnected with the lives of the vast majority of women few of whom "enjoyed the leisure to muse on masculine superiority"

It is true that the incremental achievement of formal equality in capitalist society would not eradicate the substantive economic and social inequality of working class women. Yet to insist that the demands of privileged women were not immediately connected with the reality experienced by the majority of women does not negate the ultimate importance of the issues and arguments they raised on behalf of their sex as a whole. The demand for equality has underpinned the history of feminist campaigns and struggles. As Juliet Mitchel has argued:

Equal rights are an important tip of an iceberg that goes far deeper. That they are only the tip is both a reflection of the limitation of the concept of equality and an indication of how profound and fundamental is the problem of the oppression of women. The position of women as a social group in relation to men as another social group goes far deeper, then than the question of equal rights, but not only are equal rights an important part of it but they have the most intimate connection with

40. Ibid., Miriam Kramnick, in her Introduction, 7. 42. Sheila Rowbotham, Women, Resistance and Revolution (Middlesex: Penguin Books Ltd., 1972),

The demands for education or the right to be useful were nonsensical in the situation of the poor woman....

There was no common experience for women of the effects of early capitalism. Its consequences were civerse and affected different groups of women in quite distinct expectation rather than a unifying eminist consciousness. the whole history of feminism as a conscious social and politica movement. 43

I have not yet unearthed any eighteenth century "feminist" agitation for reform of the law of petit treason, which is not to say that some women might not have raised their voices against it. But even if none did, the eventual change in the method of punishment for petit treason in 1790 and the ultimate abolition in 1828 of this special category of offence, reflecting as it did feudal obligations of subjection and obedience to one's master, were important for women. These changes represented some of the first tentative steps toward equality before the law, the extent of which, as Juliet Mitchell insists, still remains to be explored.

\section{The Law of Petit Treason}

Treason became a statutory offence in England during the reign of Edward III ${ }^{44}$ in the context of a more widespread attempt to define law with more certainty. ${ }^{45}$ The Statute of Treasons distinguished between types of treasons:

High treason it declared to be the offence against the king; petit treason the offence against the lord - thus preserving an interesting survival of the old Anglo-Saxon idea that treason is a form of treachery. ${ }^{46}$

At common law, "murders of a particular class were separated from other cases of homicide by being classified as petty treason. The offence [was] elaborately compared to the sin against the Holy Ghost." 47 According to Sir Matthew Hale, an attempt by a wife to kill her husband, the falsification by a servant of the seal of his lord, adultery by the servant with his lord's wife or daughter, and the murder of a father by. his child were all petit treason at common law. ${ }^{48}$ It is not clear whether the murder of a mother by her child was considered petit treason at common law, although Matthew Hale seems to suggest that it was not 49 The consensus of eighteenth century legal opinion was that unless a son were receiving a form of wages from his father, he could not be indicted for peti

43. Juliet Mitchell, "Women and Equality," 381-382.

45. Sir Matthew Hale, The History of the Pleas of the Crown (1736; reprint London: Professional Books Ltd., 1971), 1: 377 .

. Sir William Searle Holdsworth, A History of English Law (London: Methuen \& Co. Ltd., 1923) 2 449-450.

47. Sir James F. Stephen, A History of the Criminal Law of England (New York: Burt Franklin, n.d.), 3: 34 .

48. Hale, History of Pleas I: $378-380$. William Hawkins indicated that piracy, and discovery of the King's Counsel by one of the Grand Jury were also instances of petit treason at common law: William Hawkins, Pleas of the Crown (1716-1721; reprint, London: Professional Books Ltd.,

49. Hale, History of Pleas 1: 380 
treason if he killed him. ${ }^{50}$ William Hawkins explained that the Statute of Treasons had been "so strictly construed" that no other offence could be held to be petit treason; in particular, he referred to parricide which he implied was "in its own Nature more heinous.'’51

Both William Blackstone ${ }^{52}$ and Matthew Hale ${ }^{53}$ spoke of treason as being divided into either "high treason" or "petit treason." William Blackstone said that treason, "in it's [sic] very name (which is borrowed from the French) imports a betraying, treachery, or breach of faith." $54 \mathrm{He}$ described the gravamen of the offence:

...the breach of civil or ecclesiastical connexions, when coupled with murder, denominates it a new offence; no less than a species of treason, called parva proditio, or petit treason: which however is nothing else but an aggravated degree of murder; although, on account of the violation of private allegiance, it is stigmatized as an inferior species of treason..$^{55}$

With the 1351 Statute of Treasons, petit treason was limited to cases in which "a servant slayeth his master, or a wife her husband, or when a man secular or religious slayeth his prelate, to whom he oweth faith and obedience" 56 The punishment for men who were convicted of petit treason was to be drawn and hanged and for women to be drawn and burned.57 In fact, the punishment for all "female traitors" was the same, and (in the case of high treason in particular) differed from the punishment prescribed for men:58

But in treasons of every kind the punishment of women is the same, and different from that of men. For, as the natural modesty of the sex forbids the exposing and publicly mangling their bodies, their sentence (which is to the full as terrible to sense as the other) is to be drawn to the gallows, and there to be burned alive. 59

50. Hale, History of Pleas 1: 380; Hawkins, Pleas of the Crown 1: 87-88.

51. Hawkins, ibid. 1: 87. 52. William Blackstone, Commentaries on the Laws of England (Oxford: Clarendon Press, 1769), 4: Sir Matthew Hale, Pleas of the Crown: A Methodical Summary (1678; reprint, London: Professional Books Ltd., 1972), 9.

55. Blackstone, Commentaries 4: 75.

6. Statute of Treasons, 1351, 25 Edw. 3, St. 5, C. 2

57. Blackstone, Commentaries 4:204. Blacksto C. 2 .

who murdered their husbands derived from the "Led that the punishment of burning women

58. Blackstone, Commentaries 4: 92 .

The Punishment of high treason in general is very solemn and terrible. 1. That the offender be drawn to the gallows, and not to be carried or allowed to walk; though usually a sledge or hurdle is allowed, to preserve the offender from the extreme torment of being dragged on the ground or pavement. 2. That he be hanged by the neck, and then cut down alive. 3 . That his entrails be taken out and burned while he is yet alive. 4. That his head be cut off. 5 . That his body be divided in four parts. 6 .

That his head and quarters
59. Blackstone, Commentaries 4: 93 .

It is likely that men in positions of authority and power so feared "treachery" because precapitalist social and economic relations in England were based on "obligations of duty, subjection, and allegiance." 60 The conscious and deliberate breach of one's duty to one's superior or lord, the abuse of a confidence reposed in one by one's superior or lord, resulting in the killing of the superior or lord, was a treachery exceeded only by disloyalty to the King, which was called high treason. With respect to husbands and wives, only wives owed this duty of subjection:

If the husband kills the wife it is murder, not petit treason, because there is subjection due from the wife to the husband, but not $e$ converso. ${ }^{61}$

Sir Edward Hyde East also explained the rationale for the difference:

A wife killing her husband is petit treason; but a husband killing his wife is only murder; because of the obedience which in relation of law is due from the wife to the husband. ${ }^{62}$

Both Matthew Hale ${ }^{63}$ and Sir Edward Hyde East ${ }^{64}$ were of the view that a de facto wife who killed her "husband" could not be "perchance she may upon circumstances be a

Aiders, abettors, and procurers were caught by the statute, and the earlier cases referred to by Matthew Hale, William Hawkins, and others discuss the various situations which could or could not give rise to an indictment for petit treason. Saunders and Browne's Case 66 (c.1574) was accepted generally to stand for the proposition that if a wife was accessory to the murder of her husband committed by a stranger, she would be convicted of murder only, and not petit treason. ${ }^{67}$ If however, the principal was a servant of her husband, and the wife an accessory, petit treason would be charged against both of them. ${ }^{68}$ An exception to the rule of "accessory only where the principal be a stranger" was explained fully by William Hawkins:

60. Blackstone, Commentaries 4: 75.

61. Hale, History of Pleas 1: 381

62. Sir Edward Hyde East, $A$ Treatise of the Pleas of the Crown (London: Printed by A. Strachan for J. Butterworth and J. Cooke, 1803), 1:336.

63. Hale, History of Pleas 1: 381

65. East, Treatise 1: 337.

how this would aleas 1: 381 . Hale's use of tamen quare indicated his uncertainty or doubt as to 66. Saunders would arise or be resolved if it did.

67. Hale, History Browne's Case (1574), 73 English Reports 751, 3 Dyer. 332 b.

68. Hale History of Pleas 1: 381; Hawkins, Pleas of the Crown 1: 88; East, Treatise 1: 338. 
...[B]ut it seems clear, That if the Wife or Servant be either actually present, when the Crime is done, or present only in Judgment of Law, as being in the same House, but not in the same Room, (in which case the Hopes of their immediate Assistance encourages and imboldens the Murtherer to commit the Fact, which otherwise perhaps he would have dared not do, and makes them guilty in the same Degree as if they had actually stood by with Swords drawn, ready to second the Villainy, such Wife or Servant, being Principals as much as the Stranger, are guilty of Petit Treason. ... ${ }^{69}$

This statement of the law would explain the indictment in 1713 of Mary Sayer for petit treason in the death of her husband, John Sayer, who had died by the sword of her attorney and lover, Richard Noble ${ }^{70}$ Although Noble himself was not caught by the statute, he had killed John Sayer in Mary Sayer's presence. John Sayer had obtained a warrant "for taking into custody the body of Mary Sayer his wife, who...was gone from him without his consent, and lived in a loose scandalous manner,"71 and he was killed in the attempted execution of this warrant. On the evidence, it appeared (and Noble himself insisted) that neither Mary Sayer nor her mother, who also stood charged with murder out of the same incident, had had any involvement in the killing. They were both acquitted; 72 he was convicted of murder and executed.

To be petit treason, the killing had to involve "treachery" or malice aforethought; therefore, if the deceased had been killed in circumstances of a "sudden falling out" or "sudden provocation"73 or in the course of the accused"s "necessary self defence," added William Hawkins, it would not be petit treason, but only manslaughter. ${ }^{74}$ For example, Lydia Adler was convicted for manslaughter of her husband at the Old Bailey in $1774,{ }^{75}$ and while it is difficult to determine from the reported account of her trial, the absence of any evidence of a planned attack must have been of some significance. Similarly, while the following entry relating Margaret Ryan's execution is sparse, it would appear that she was convicted only of wilful murder in the death of her husband:

At Maidstone [Assize], eight [were executed]; amongst whom was Margaret Ryan, for the wilful murder of her husband. She pleaded

69. Hawkins, ibid. 1: 88

70. The Trial of Richard Noble, Mary Sayer and Mary Salisbury (1713), 15 State Trials 731 71. Ibid., 737.

On the acquittal of the two ladies, they behaved so overjoyed, as to be taken notice of by the Court, who reprimanded them for their indecent behaviour... Upo their being discharged, the two ladies returned to London in a coach, taking with them the turnkey to prevent any insult from the mob, which was pretty numerous. Whilst in the coach, the ladies seemed overjoyed at their deliver 3. Hale, History of Pleas $1: 378$.

74. Hawkins, Pleas of the Crown 1: 88.

75. Old Bailey Sessions Papers, June 1744, 166 guilty; but, at the desire of the court, she put herself on her country. She appeared to be near 70, and only said in her defence "the deceased and she had words, and she stabbed him with a pen-knife". ${ }^{76}$

Thus, conspiring or planning in advance to kill one's husband or master was an essential element which raised ordinary murder to "high murder," or petit treason.

\section{Procedural Issues}

The early case of Pigot v. Mary Pigot \& Elizabeth Lewen ${ }^{77}$ established the right of the heir, in this case the son, to undertake the prosecution of a case involving an allegation of petit treason. However, the fact that petit treason was contained within the Statute of Treasons meant that the procedure at trial was not governed by the common law. As William Eden explained:

Petty treason, in our law, differs widely from other instances of murder, in certain privileges given to the defendent; such are, the power of a peremptory challenge of thirty-five jurors, and the requisitions of two witnesses to the indictment and at the trial..$^{78}$

The precise relationship between murder and petit treason was a difficul one for the legal commentators; was it a species of murder or a species of treason? Matthew Hale's view was that "a man or woman, that commits petit treason may be indicted of murder." 79 Michael Foster agreed with Matthew Hale's view of the law, but elaborated:

But though I am satisfied that the law considereth Petit Treason and Murder as one Offence differing only in Circumstance and Degree, yet whether it may be advisable to proceed upon an Indictment for Murder against a Person plainly appearing to be guilty of Petit Treason is a Matter that deserveth great Consideration. ${ }^{80}$

Michael Foster was concerned that a person charged with murder, whose trial established the requisite relation with the deceased meriting a charge of petit treason, ought not to be able to be acquitted of the murder:

76. Chronicle, Annual Register 19 (April 1776): 138.

1. Pigot v. Mary Pigot and Elizabeth Lewen (1639), 79 English Reports 1060. Cro. Car. 532. See also,

"Eden, Principles, 242. For another assessment of these procedural privileges, see Campbell, "Sentence," 52-53.

80. Foster Crown Law, 327 
For a person charged with a crime so heinous a Nature ought not to have the Chance given him by the court of availing himself of a Plea of Autrefois Acquit. ${ }^{81}$

William Hawkins seems to have had a different view of the relationship between the two offenses; in his words (and he too relied on Matthew Hale as his authority for this proposition):

And therefore it seems agreed, That Persons accused of Petit Treason shall be construed to be either not guilty at all, or Principal or Accessory. . .: For inasmuch as all Petit Treason implies Murther, they cannot make it Petit Treason; and vice versa, generally whereever the Circumstances are such as to make the killing of a Stranger by Stranger Murther*, they make the killing of a Husband, or Master, etc., Petit Treason. 82

While William Hawkins did not address the issue raised by Michael Foster concerning the procedural problem, it seems from the above that he would have resolved it differently.

In fact, Michael Foster's interpretation of the law (that murder was an included offence in petit treason) was adopted in $R$. v. Henrietta Radbourne in $1787 .{ }^{83}$ Henrietta Radbourne stood accused of petit treason in the death of her mistress. The evidence against her was entirely circumstantial; the mistress had not been able to identify her assailant, and in sum, "there was not any set of circumstances proved by two witnesses." 84 The court held that Henrietta Radbourne could not then be convicted of petit treason, but convicted her of murder. The acquittal for petit treason was thus not a bar to her conviction for murder upon the same indictment. The form of death penalty she then faced was different, as her conviction for murder brought a sentence of death by hanging.

Joseph Chitty in his Practical Treatise 85 insisted that the indictment had to allege both wilful murder and treason if a conviction for petit treason was sought if the reference to "traiterously" was omitted from the indictment, the conviction could only be for murder. It may be that a prosecutor had a discretion with respect to proceeding with the lesser (i.e. wilful murder) indictment in a case which might on its merits be petit treason. The problem of proof, and possibly the difficulty in securing a second witness might have led prosecutors to proceed with the lesser offence. As well, some prosecutors might have been inclined to spare women the terrible punishment which a conviction for petit treason brought.

81. Foster, Crown Law, 328

82. Hawkins, Pleas of the Crown 1: 88.

83. The King v. Henrietta Radbourne (1787), 168 English Reports 330, 1 Leach 456

84. Ibid., 332; The Lawyer's and Magistrate's Magazine 3 (1791): 148.
85. Joseph Chitty, A Practical Treatise on the Criminal Law (London: A.J. Valpy, 1816) 3: 743-744.

\section{Evidentiary Issues}

\section{Proof of Marriage}

Although both Matthew Hale and Edward Hyde East were of the view that a common law wife could not be convicted of petit treason in the killing of her husband, the limited case law on point seems to indicate that in fact a fairly low standard of proof of marriage was required. Edward Hyde East referred to the case of Mary Norwood, who was tried at the Taunton Lent Assize in 1765 for "traiterously poisoning and murdering her husband Joseph Norwood" "86 Her counsel had argued that for a conviction of petit treason, proof of actual marriage was required, such as either a copy of the registration of marriage, or the testimony of someone who had been present at the ceremony. The court held that such formal proof was not required, and relied on the evidence of their seven-year cohabitation as "man and wife," the fact that Joseph and Mary ("after the poison") had referred to each other as "husband" and "wife," and the evidence of Mary's brother who had lived with the couple six years earlier, and "spoke of knowing them ever since they were married."87 That Mary apparently had gone to a neighbour about a year before her husband's death and asked him "whether she had better poison her husband or part from him, for one or the other she must do", 88 might well have had a bearing on the outcome of the trial. She is undoubtedly the same Mary Norwood whose execution is referred to in the April issue of the Annual Register for 1765:

At Sommerset assizes, five were capitally convicted; but all were reprieved, except Mary Norwood for poisoning her husband, who was burnt at Ivechester on the 11th of May. ${ }^{89}$ (emphasis added)

Lydia Adler, referred to earlier, was convicted of manslaughter in the death of her husband John Adler, who had died twelve days after being knocked to the ground, kicked, and stamped upon by Lydia, or so he said. ${ }^{90}$ The examining surgeon had not been able to say with certainty that the "mortal bruise" was in fact a recent injury. Lydia Adler, for her part, gave a different version of the incident, and in fact accused one of her husband's other wives of causing the injury. Another witness confirmed that the deceased had several wives:

Prisoner

(Lydia Adler)

My husband loved women, he had got 2 wives besides me; he had a crew he lived with in St. Giles's, and one of them gave me a slap of the face; I asked her what she did here? and she said he was her husband and struck me. .

86. East, Treatise 1: 337

87. Ibid.

89. Chronicle, Annual Register 8 (April 1765): 81

90. The Trial of Lydia Adler, Old Bailey Sessions Papers (June 1744): 166. 
Joseph Steele I have known the Prisoner about nine or ten years. Mr. Adler (Witness) was acquainted with another woman in Golden-lane that he had two children by; he was always a loving man to his wives at first....

Joseph Steele ...this is his fourth wife, and they were all served in the same kind. ${ }^{91}$

Jane Butterfield was acquitted at Croydon in August 1775 after her trial for the wilful murder of William Scawen, her benefactor of many years. ${ }^{92}$ The medical evidence was far from conclusive that the deceased had been poisoned by the accused. As well, there was compelling evidence of her good character and affection for the deceased. ${ }^{93}$ There was not even a hint of petit treason, notwithstanding the accused's own description of her relationship with the deceased:

She confessed that Mr. Scawen had spared no expense in perfecting her education, and that he had shown so many instances of friendship and kindness to her, that she tenderly loved him, and had, by a conduct of many years, convinced him of her affection and gratitude.... She declared she had been treated by the whole family as Mrs. Scawen, and was received in the neighborhood in the same character. ${ }^{94}$ (emphasis added)

Scawen might have had a legal wife, which would have brought Butterfield within the exception enunciated by Matthew Hale and Edward Hyde East, or she might simply have been regarded as the "lady of the house", in the absence of a wife. It is impossible to know, from the information contained in the Annual Register's account of her trial. In any event, on the basis of Mary Norwood's case, it would appear that cohabitation, and more, was required to prove the marriage relationship in a charge of petit treason, but arguably not very much more.

\section{Proof of Murder}

One might not ordinarily expect a discussion of the method of murder in an examination of the law and its history; however, because "women and poison and murder" seem to have been inextricably entwined throughout the centuries, it

91. Ibid., 167-168.

92. Chronicle, Annual Register 18 (August, 1775): 233-237.

. Chronicle, Annual Register 18 (August, 1775): 237. One witness for the accused, Miss Smith, dicated that she had known both the deceased and the Prisoner well:

This witness declared she did not believe that the prisoner poisoned Mr. Scawen, as whom should of such

94. Chronicle, Annual Register 18 (August, 1775): 235. merits comment in this article. Poison has had a rather special place in English law. For a brief period in the sixteenth century, wilful poisoning was high treason, and a person convicted was to be boiled to death. ${ }^{95}$ In the eighteenth century, if one was "in danger of poisoning" from one's spouse, it was thought to be "good cause to pronounce a Sentence of Separation." 96 A nineteenth century medical jurisprudence article assured its readers that the "art of poisoning, in all ages of the world, has been chiefly indebted to the female sex for its scientific cultivation." 97 The American criminologist Otto Pollak, writing in 1958 on the "masked" nature of female criminality, did little more than confirm this long-held assumption. $98 \mathrm{He}$ did, however, suggest that as women's sphere is often the home, their "social roles" as cook and nurse could explain why they might resort to arsenic, for instance, as a weapon. In fact, if one considers that people who kill might be more inclined to use weapons which are either familiar or handy, it is not surprising that women might resort to their kitchen tools to murder.

John Beattie's study of female crime in eighteenth century England tends, however, to challenge Pollak's assertions:

Nor is it apparent that when women in the eighteenth century resorted to murder, to take the most serious of the crimes against the person they turned naturally to devious methods, as has been suggested of their modern counterparts, or they favoured weapons, like poison, that compensated for their lack of physical strength. ${ }^{99}$

Of the fifteen women in Beattie's Surrey sample who were indicted as principals for murder, four had struck their victims on the head ("with a club, poker, iron spit, and pewter drinking pot"), and three had used knives. ${ }^{100}$ Admittedly, his sample is not large and there is no suggestion that any of these women were indicted for petit treason. Contemporary work on American women who kill suggests that women continue to use knives or household implements in a large number of cases. ${ }^{101}$

Just under half of the women indicted for petit treason whose cases I have

95. Sir Leon Radzinowicz, A History of the English Criminal Law (London: Stevens \& Sons Ltd., 1948), 1: 629; George Ryley Scott, The History of Capital Punishment (London: Torchstream Books, 1950), 24-25. Both Radzinowicz and Scott refer to the case of the Bishop of Rochester's cook who poisoned several members of the Bishop's household; he was executed in 1530. Scott also refers to the case of a "servant girl" who was executed in 1531 for poisoning her mistress. 96. The Lady's Law, 167,

7. "Art. II Medical Jurisprudence. No. II Poisons," Quarterly Review 2 (1829): 30

99. Otto Pollak, The Criminality of Women (New York: A./S. Barnes \& Co., Inc., 1961), 13-17.

90. Ibid of the remaining eight three had been

tossed a complaining elient had either punched or kicked a second floor window, one had used a pistol, and two others

1. David A. Ward, Maurice Jackson and Resulting in death.

Women, Crime and Justice, ed. Susan K. Datesman and Frank R. Scarpitti (Oxford: Oxford University Press, 1980), 186. Their study indicated that women used these types of weapons in almost half the assaults and one third of the murder cases. 
found were executed for poisoning their victims. ${ }^{102}$ The twenty-seven found (collected primarily from printed sources such as The Gentleman's Magazine, ${ }^{103}$ the Annual Register, and the wildly moralistic Knapp and Baldwin Newgate Calendar) include thirteen cases of women executed for petit treason in which poison was found to have been the method of murder. Added to these may be perhaps the most famous poisoning case of the eighteenth century, ${ }^{104}$ the case of the "fair parricide," Mary Blandy, executed in 1752. ${ }^{105}$

Some of the methods of poison are referred to in the accounts of cases. Sarah Pledge and Ann Whale were executed in 1752 for poisoning Ann's husband, James Whale:

For this purpose Pledge, the woman, first attempted to poison him by roasting spiders to put in his beer; but his wife relenting when she was about to administer them, some white mercury was afterwards procured by Mrs. Pledge, and Whale's wife, and mixing it with hasty pudding, while he was intently gazing on his child, he ate it, and died within a few hours. 106

Ann Williams also was accused of mixing white mercury into her husband's food, some "pap;" a description of his death also appeared in The Gentleman's Magazine, along with a brief account of her execution at Gloucester in April, 1753:

. .after he had eaten the pap, she desired him to draw her some drink, which he did, and drank some of it himself, when he was immediately seized with violent vomitings and purgings; that her husband told his sister, that his wife was a wicked woman, that he was very well till after she made him eat some pap, which (he said) had done his business for him, and that he should die; and he did die on the morrow, when his body appeared as if mortified. ${ }^{107}$

102. See Appendix I The Gentleman's Magazine is considered by Jean E. Hunter to be a "fertile source for popular
ideas about women" as it was "the most popular, most widely read, and most successful eighteenth-century journal" and also because it was directed to the general literate public and read by women and used contributions by women: Jean E. Hunter, "The 18th-Century Englishwoman: According to the Gentleman's Magazine," in Woman in the 18th Century and Other Essays, eds. Paul Fritz and Richard Morton (Toronto: Samuel Stevens Hakkert \& Co.

1976), 73, 87.
Mary Blandy's case was followed closely in The Gentleman's Magazine 21 (November, 1751): 377 , 68-488; 22 (April, 1752): 108-117, 152-155, 188-189; See also William Roughead, ed., Trial of Mary Blandy (Glasgow: Wm. Hodge \& Company, 1914)

. In 1829 , seventy-six years after her execution, the medical evidence led at her trial, through a Dr. Addington, of the tests for arsenic performed on the "white powder" she put in her father's
gruel, was still considered and relied upon. See for instance, the article on poison "Art II grued, was still considere
Medical Jurisprudence.'

107. The Gentleman's Magazine 23 (April, 1753): 198.
Them
Ann Williams went to her death denying her guilt.

Mary Blandy had been accused of administering arsenic to her father over a long period of time, the cumulative effect resulting in his death. While hers was not a case of petit treason, the charge of murdering one's father was regarded with a parallel degree of horror. Mary Blandy also went to her death denying her guilt; in her declaration from the tree, she described herself as "the innocent cause of his death." 108 She had admitted administering the "white powder" which had been found in her father's food. Shortly before her father's death, she

..owned that she had, at several times, mixed in her father's water gruel a love powder which she had received from Captain Cranston [her lover], but she believed it to be quite harmless; that the captain had sent her a present of Scotch pebbles, and that this powder accompanied them. Being asked why she did not take some herself, if she believed them harmless? to this question she gave no satisfactory answer. ${ }^{109}$

Mr. Blandy had not approved of Cranston, and so the love powder was intended to turn his heart around. Mary Blandy was seen by some as an innocent dupe of a "base and barbarous man." 110 Her father himself, when asked before his death who had given him the poison, was reported to have replied, "with a smile of sorrow, 'a poor lovesick girl I believe, but I forgive her'" '111

Mary Blandy's defence, essentially one of lack of mens rea, did not succeed and the suggestive reporting of her conduct while in prison ${ }^{112}$ might have affected public perception of her credibility and innocence. Her trial and execution generated considerable comment in The Gentleman's Magazine; 5000 people attended her execution, "many of whom, and particularly gentlemen of the university, shed tears." 113 One interesting comment was printed after the execution of Elizabeth Jeffreys (who, with her uncle's servant had been convicted of the uncle's murder) ${ }^{114}$ and just before the execution of Mary Blandy:

Nothing is so common, and at the same time so erroneous, as the assertion that this or that murder committed of late, is the most cruel and astonishing that ever was heard of. This is now advanced

108. The Gentleman's Magazine 22 (April, 1752): 189

109. The Gentleman's Magazine 22 (March, 1752): 109-110.

110. One correspondent in The Gentleman's Magazine 22 (March, 1752): 116: The villain crept into the unguarded heart of this thoughtless girl. There he firs infused those poisonous sentiments, which were afterwards to convey arsenic into the veins of the best and tenderest of fathers.

111. The Gentleman's Magazine 21 (Movember 1751): 377 :

After she had been in prison some time, being ask'd how she could perpetrate such aruel deed, she reply'd, 'she did not think there was any crime to dispatch a cross old fellow out of the way, who was the only bar to her happiness, and that she would Genit, was it to be done again'

114. The Gentleman's Magazine 22 (March, 1752): 121-125. 
particularly with relation to Miss Blandy and Miss Jeffreys, for want of hearing, or perhaps recollecting what has been done in the last century; or even some murders that have been perpetrated this very year, which are no less shocking, tho' less talk'd off [sic].

$$
\cdots
$$

What exclamations are now made on female cruelty! Yet a gentleman may starve, or otherwise destroy wife after wife, and have the character of sanctity; . . 115

While the thought of a love powder may seem to be ludicrous today, "love drops" or "love powder" were advertised and sold in English markets. 116 They were said to make the recipient return the love of the donor, as one advertisement for love powder promised:

If a woman has got a husband that goes astray, let her give him a few of these drops, and it will make him rest at home, and never desire to go no more. 117

The account of the death of one recipient of such a love powder was reported in 1738:

A Journeyman Peruke-Maker, having a large dose of Cantharides given him by a woman in some coffee as Love Powder died in a miserable Manner, his Throat being so blister'd, that he was incapable of swallowing: the Coroner's Jury brought in their verdict wilful Murder, and the woman is in custody. 118

Clearly, lethal substances were available from sources other than apothecaries, and for well-intentioned and even useful purposes. ${ }^{119}$ The determination whether someone had administered such substances with an intention to kill must have involved some consideration of the suspect's character and relationship with the deceased. Certainly, in Jane Butterfield's case, no one

115. Ibid., 125 .

16. William Roughead, ed., Trial of Mary Blandy (Glasgow: William Hodge \& Co., 1914), Appendix VI, $186-187$.

117. Ibid., 187.

118. The Gentleman's Magazine 8 (December, 1738): 659.

Arsenic undoubtedly was used to keep the rodent population in control: see "Art II Medical Jurisprudence:" 40 . Mercury was thought to have curative qualities, and was used by both apothecaries and surgeons to treat open sores; see Mr. Scawen's prescribed treatment in "The suggested that the apothecary, who had originally prescribed mercurial ointment for the ulcer on Mr. Scawen's arm, had acted malevolently; and, indeed, as noted earlier, evidence of the accused's tender affection for the deceased seemed to assist her in her trial. 120

\section{Coroner's Juries}

Before proceeding to a consideration of the implications of character evidence for women charged with petit treason, some mention must be made of the use of coroner's juries in the detection of these murders. This issue merits further research and accordingly, my comments here will be brief. Some of the cases referred to in The Gentleman's Magazine and the Annual Register mention the verdict of a coroner's jury. Indeed, two of the women, Amy Hutchinson and Margery Beddingfield, were charged only after the arousal of public suspicion had resulted in the bodies of their husbands being "taken up" after burial and a coroner's inquest held. 121

In a fuller account of the Beddingfield murder, the Annual Register reported that an inquest had been held shortly after the husband's death, with a verdict of "accidental death" being entered. John Beddingfield had been strangled in his bed by his wife's lover, Richard Ringe. After his body was discovered, and laid out, "the servants. . .took notice that his face was black, and his throat and neck almost round." 122 The account continues:

The next day the coroner came; but his inquest seems to have been very negligently and superficially taken.

$$
\ldots
$$

One Sparham, a surgeon, was also examined: $\mathrm{He}$ found the coroner in a great hurry to go home; he took a hasty view of the body; was of the opinion that the blackness of the face was occasioned by the deceased's own fingers; and having with great expedition dispatched the impatient coroner, went away, without having been in the house frve minutes. 123

Some weeks later, when the love affair between Richard Ringe and Marjery Beddingfield was cooling ("thus deceitful and transient was the pleasure for which she had, at the risk of life, violated the most sacred obligation, and contracted the most aggravated guilt"), 124 a young servant revealed the truth of the death, and a trial and executions followed in March and April, 1763.125

120. Chronicle, Annual Register 18 (August, 1775): 233-237.

121. Amy Hutchinson's case, The Gentleman's Magazine 19 (November, 1749): 486; Margery Beddingfield's case, The Gentleman's Magazine 32 (October, 1762): 500

122. Chronicle, Annual Register 6 (1763): 168, 172.

123. Ibid., 172-173.

124. Ibid., 173. 
J.D.H. Havard, the British medical legal authority, suggests that early practice among coroners was to hold an inquest only in cases where there was "manifest evidence of violence;"126 thus, "the majority of cases of murder by poison or other 'secret' methods of killing went unrecognized." 127 From the account of the Beddingfield inquest, it is clearly possible that some "not so secret" homicides likewise went undetected. In rural communities, local gossip may have facilitated the task of the coroner and his jury, particularly if young women such as Margery Beddingfield or Amy Hutchinson were seen not to be conducting themselves in the modest mournful way expected of bereaved widows.

\section{Evidence of Character}

The importance of character evidence in criminal trials in the eighteenth century has been illustrated by Douglas Hay, 128 John Langbein, ${ }^{129}$ and John Beattie $^{130}$ in their respective work. John Beattie suggests that evidence of the prisoner's character was "often crucial to the outcome of the trial."131 Where the evidence against the accused was weak or circumstantial, her "bad" character might tip the balance against her, as may have happened in Henrietta Radbourne's trial for murdering her mistress. Radbourne had accused two other people, Henry and Rebecca Holmes, of killing her mistress. She said that she had let them into the house on the night in question

[B] ut it appeared, that there had been a violent quarrel between [Henry and Rebecca] Holmes and the prisoner, on account of their having refused to carry messages for her to the man whose name she had assumed, and with whom she had been connected, but who had abandoned her on account of her bad character, and disposition to tell lies: and, indeed, both Holmes and his wife, who were examined as witnesses on the trial, not only denied the fact, but appeared free from all imputation. ${ }^{132}$

In the cases referred to thus far, the character of the women alleged to have "violated the most sacred obligation" was clearly an issue in their trials. Nothing could be more critical in this respect than the suggestion or proof of marital misconduct on the part of an accused wife. Contemporary attitudes may have been reflected in a story in The Gentleman's Magazine in 1731:

126. J.D.H. Havard, The Detection of Secret Homicide (London: MacMillan \& Co. Ltd., 1960), 39. 127. Ibid.

128. Douglas Hay, "Property, Authority and Criminal Law," Albion's Fatal Tree, ed. Douglas Hay et al. (New York: Pantheon Books, 1975), 42-43.

129. John Langbein, "The Criminal Trial before the Lawyers," The University of Chicago Law Review 45 (1978): 263, 288-89.

130. Beattie, Crime and the Courts, 440-47.

131. Ibid., 440 .

132. The King v. Henrietta Radbourne (1787), 168 English Reports 330, 332.
We generally find Adultery the fruitful root of Matrimonial Murders. Some indeed have done it for Lucre; as that Essex Chap, who used to marry tender Constitutions in the Uplands, and to bring them down into the damp unwholesome Hundreds when he was soon at Liberty to go to market for fresh ones. ${ }^{133}$

Treachery it seems was not confined to women.

The consequences of infidelity in marriage were thought to be inevitable. The following entry in the Annual Register did not name the individuals involved, but the theme of women "inflexibly bent" on a husband's destruction was often repeated: 134

A farmer's wife having contracted an affection for a young fellow in the same village, and often expressing her desire for the death of her husband, that she might enjoy the wickedness of her heart, the young fellow very soon completed her wishes; ${ }^{135}$

This would explain why in the trial of Mary Sayer and Richard Noble, evidence not only of their relationship prior to her husband's death, but also the testimony of a midwife who had attended Mrs. Sayer in childbirth, delivering a baby who the midwife believed to be Noble's child, ${ }^{136}$ was important. This evidence addressed more than motive. Mary Sayer's acquittal illustrates that evidence of a woman's bad character was not necessarily determinative; however, that her co-accused was a gentleman who insisted on her innocence clearly helped her case.

\section{The Penalty}

The question of punishment is always central to any discussion of crime and criminal law. Petit treason offers no exception. The procedural privileges available to a woman so charged were likely of little interest to her, or to the crowd that gathered to witness her execution. Until the last decade of the eighteenth century the British Parliament countenanced and even defended the practice of burning wives convicted of murdering their husbands, women servants who murdered their masters, and women convicted of high treason, usually coining. 137 Leon Radzinowicz suggests that this form of punishment was "conceived as a mitigation" of the penalty prescribed for treason. ${ }^{138}$ A further mitigation was said to occur in practice: "the humanity of the English nation

133. "Matrimonial Murders," The Gentleman's Magazine 1 (November, 1731): 463.

134. See the stories of Catherine Hayes: William McAdoo, The Procession to Tyburn (New York: Bon and Liveright, 1927), 39-69. Elizabeth Boardingham: Chronicle, Annual Register 19 (April, 1776): 138; Edith Morrey: Chronicle, Annual Register 54 (1812): 53-54, 106-107; 55 (1813): 31 .

135. Chronicle, Annual Register 9 (February, 1766): 65

136. The Trial of Richard Noble, Mary Sayer and Mary Salisbury (1713), 15 State Trials 731, 736.

137. Radzinowicz, A History, 1: 209-213; Scott, Capital Punishment, 31. 
authorized by a tacit consent"139 that a prisoner could be strangled prior to being burned. The execution of Susannah Lott, who (with a man named Benjamin Buss) was executed in 1769 at Canterbury for poisoning her husband, might have been typical:

A post, about seven feet high, was fixed in the ground; it had a peg near the top, to which Mrs. Lott, standing on a stool, was fastened by the neck; when the stool was taken away, she hung about a quarter of an hour, till she was quite dead: a chain was then turned around her body, and properly fastened to the post, when a large quantity of faggots being placed round her, and set on fire, the body was consumed to ashes. ${ }^{140}$

The Annual Register's reporter indicated that 5000 persons attended this execution. ${ }^{141}$

It is significant that the strangulation process was not part of the official sentence. ${ }^{142}$ And although William Blackstone insisted that there were only "very few instances (and those accidental or by negligence)" 143 where a prisoner was actually burned alive, George Ryley Scott argues that "accidents and carelessness" might well have characterized these executions. ${ }^{144}$ Even if everything went "smoothly", as appears to have been the case in Susannah Lott's execution, Scott suggests this particular method of "mitigation" was:

a hit-and-miss method at best, and one which must surely have entailed a very slow process of strangulation while the flames raged around her
body. ${ }^{145}$

It does seem that instances of women actually being burned without the "benefit" of strangulation were rare; the only case that is consistently referred to because it is seen as exceptional, is that of Catherine Hayes in $1726 .{ }^{146}$ Michael Foster wrote (apparently of her case):

I remember a Woman for the Murder of her Husband under circumstances of high and uncommon Aggravation literally Burnt Alive. ${ }^{147}$

139. Blackstone, Commentaries 4: 370

140. Chronicle, Annual Register 12 (July, 1769): 117. See also Campbell, "Sentence," 45.

141. Ibid. Scott, Capital Punishment, 31.

143. Blackstone, Commentaries 4: 370

144. Scott, Capital Punishment, 31

145. Ibid., 105 .

147. Radzinowicz, A History 1: 212
The inference is that few women suffered as extremely as she did. The officia explanation was that the flames had reached the executioner's hand forcing him to drop the rope before he could strangle her. ${ }^{148}$ However, it has also been suggested that the crowd at the execution would not allow the executioner to strangle her. ${ }^{149}$

It is possible that an angry crowd could have influenced the extent to which a particular sentence was mitigated. The crowds were large, ${ }^{150}$ undoubtedly drawn by the promise of a spectacle. In fact, if Andrew Knapp and William Baldwin's description of Ann Williams' execution is at all accurate, it may be that she too was burned alive. The entry in the Gentleman's Magazine indicated simply that she had been "burnt at a stake at Gloucester," 151 without any reference to her being strangled beforehand. Andrew Knapp and William Baldwin, writing in 1825 , described the scene at her execution:

The horrid crime being fully proved against her, she received sentence to be burnt at the stake, which sentence was accordingly carried into execution at Gloucester, April 3, 1753, among a number of spectators, who showed little pity for her fate, and which became still more shocking from denying the fact, so incontrovertibly proved, to the very last moment of her existence. ${ }^{152}$

A particularly hostile crowd at the execution of a particularly unpopular prisoner might have influenced more than one executioner to drop the rope when the "flames reached his hand." Not only was Ann Williams a fiend guilty of an abominable crime; worse yet, she denied it. Other women were depicted as more

Radzinowicz, A History 1: 212; Campbell, "Sentence," 45.

50. Radzinowicz, A History 1, 211, says that twenty thousand attended the 1786 execution of Phoebe Harris, in front of Newgate. According to a correspondent in Notes and Queries, 1st ser. 2 (June, 1850): 6 , the post, to which a woman had been bound and burned for petit treason, was still standing some sixty years after her execution. She and her lover, a marine, had been convicted for the murder of her husband. This correspondent had interviewed an eyewitness to the execution, who described the even

I can't recollect the year, but I remember the circumstance well. It was about sixty-five years ago [interviewed in 1848]. I sat on my father's shoulder and saw them bring her and the marine to the field. They fixed her neck by a rope to the

stake, and then set fire to the faggots, and burnt her.

's execution was recorded in The

itch after a short prayer the executioner st, and having a garment dawb'd with fire was kindled, and burnt half an hour.

Mary Hilton was convicted for poisoning her husband, and "ordered to be strangled, and afterwards to be burnt." Chronicle, Annual Register 15 (April, 1772): 94. Likewise, "Elizabeth Boardingham's body was burnt to ashes." Chronicle, Annual Register 19 (April, 1776): 138. References to the executions of Mary Heald (1763), Mary Norwood (1765), Ann Sowerby (1767) indicate simply that each was "burnt." Chronicle, Annual Register 6 (April, 1763): 71-72; 8 (April,

. Andrew Knapp and William Baldwin, The Newgate Calendar (London: J. Robins \& Co., 
modest and contrite; Susannah Lott "was very sensible of her crime and died entirely penitent." 153 Mary Fasson (or Fawson) conducted herself in like manner:

Her behaviour in prison was with the utmost rigour of contrition. She would not, to gratify people's curiosity, be unveiled to any. She confessed the justice of the sentence, and died with great composure of mind. 154

The fact that a woman convicted of a capital offence was able to delay her execution if she could satisfy a jury of matrons that she was pregnant beyond the point of quickening affected a few women convicted of murdering their husbands. The delay in the date set for Catherine Nairne's execution gave her an opportunity to escape after the birth of her child, and she made her way to France without being recaptured. ${ }^{155}$ Nairne's case was covered extensively by both the Annual Register and The Gentleman's Magazine in 1765 and 1766. She was prosecuted under Scottish Law and hence I have not referred further to her case. Popular wisdom among prisoners awaiting trial, and the population more generally, may well have been that "pleading her belly" was a way for a woman to "get off" at the assizes. ${ }^{156}$ Given that men and women were housed together in the county gaols, the "promise" of the reprieve may have led to women being seduced or raped by fellow prisoners. This was surely Amy Hutchinson's experience in gaol prior to her execution in 1749 at Ely. Abandoned by her lover "T.R.", alone and afraid, the tragedy of her plight revealed in her description of her experience in gaol is compounded when we realize that she was sixteen years of age when executed for petit treason in the death of her violent husband. In her words:

For being quite forsaken by T.R. who never visited me after I was first in custody, and apprehensive of the sentence of death, I was drawn, partly by the insinuations of one T.N. a fellow-prisoner, pretending it would be a means to get off at the assizes, and partly by force, to suffer what I ought to have complained of as a rape; for he stopped my mouth with my apron; but I did not make a complaint till a fortnight after. ${ }^{157}$

While pardons were used widely in eighteenth century England, thus mitigating in practice a harsh penal code, ${ }^{158}$ in none of the cases I have found did

153. Chronicle, Annual Register 12 (July, 1769): 117

154. Notes and Queries, 1st ser., 2 (May, 1855): 373. See also Campbell, "Sentence," 45-46 for The London Magazine's account of her execution.

155. The Gentleman's Magazine 36 (March, 1766): 148. Nairne's case was covered extensively by both the Annual Register and The Gentleman's Magazine in 1765 and 1766. She was prosecuted unde 156. Beattie, Crime and the Courts, 430-31. Certainly, John Beattie is

execution pending courts, 430-31. Certainly, John Beattie is of the view that a reprieve from 157. The Gentleman's Magazine 19 (November 1749): 486 .

158. Hay, "Criminal Law," $43-49$. a woman convicted of petit treason receive a pardon. ${ }^{159}$ All were executed. This fact may not be significant, given the few cases; however, it is interesting to note that pardons for people convicted of either wilful murder or high treason, while not overwhelming in number, were not unheard of. 160 Indeed, John Beattie has argued that women were more likely than men to be reprieved and pardoned; his research revealed that 75 per cent of the women (112 out of 149) convicted of capital offenses were pardoned. ${ }^{161}$ That the penalty was so rarely inflicted was one of the stated reasons for not altering it. ${ }^{162}$ The same reasoning may have prevailed in the non-extension of pardons for the women convicted of petit treason. The ideological significance of the "rare" event must not be overlooked; as Beattie has observed:

[t]he broader purposes of the law and of the administration of justice could be served by the very occasional example of a woman harshly dealt with. 163

\section{Reform of the Law of Petit Treason}

William Eden, a proponent of criminal law reform in the eighteenth century, was one of the first to call for the abolition of this form of death penalty for women and for the introduction of hanging as the regular penalty for treason 164 Although he argued against the burning of women convicted of high or petit treason, he was not offended by the concept of "aggravated" murder caught under the rubric of petit treason; in fact, he thought it unfortunate that parricide was not considered petit treason. 165

In accordance with his position on the infliction of capital punishment, William Eden found the penalty provided for treason to be harsh:

...when we are constrained to have recourse to that fatal extremity, it should always be observed, that whatever exceeds simple justice is more cruelty. Every step beyond is a trace of ancient barbarity, tending only to distract the attention of the spectators and to lessen the solemnity of the example. 166

159. See Appendix I: all the women convicted were executed.

60. Report of the Select Committee on Criminal Law Relating to Capital Punishments in Felonies with Minutes of Evidence (1819), I, Appendices 6, 7, and 8 indicated that between 1689-1814, there Were 8 convictions and 8 executions for petit treason in the Home Circuit. With respect to the treason between 1770-1818. Appendix 10 of the Report also dealt with the statistics for petit Western Circuit, indicating inter alia that 3 out of 5 people convicted for high treason were reprieved, 9 out of 29 convicted of rape were reprieved, and 16 out of 133 convicted of murder were reprieved.

161. Beattie, Crime and the Courts, 436-38.

162. U.K. Parliamentary Debates (Lords) 23 (1786), Cols. 93-94.

163. Ibid., 439.

164. William Eden, Principles of Penal Law (London: Printed for B. White, 1771), 241

165. Ibid., 243. 
He referred to the case of Elizabeth Gaunt, the last woman to be executed for a political offence. ${ }^{167}$ Elizabeth Gaunt had given shelter to a rebel, on whose evidence she had been convicted of high treason. That the rebel "was pardoned for his treachery," while "she was burned alive for her charity" clearly offended him, although another inference may be that he was as opposed to the extension of the pardon in a case of high treason as he was to the burning of women.

William Eden clearly supported public executions, but seemed anxious to maximize their impact. His position against the burning of women for high or petit treason was paradoxical, given that he thought parricide ought to have been included within the category of petit treason, and regretted that it was not "subjected by our laws to any degree of exemplary notice."168 What more "exemplary notice" there could be than the provision of a particularly terrifying form of execution is unclear.

William Eden's work on penal law was first published in 1771; Sir Samuel Romilly likewise addressed the issue of petit treason and murder, but this work was never published. ${ }^{169}$ The first attempt to alter the form of penalty provided for women convicted of treason came in June 1786 in a bill introduced by prominent Evangelical William Wilberforce. ${ }^{170} \mathrm{His}$ bill proposed not only to change the penalty for women convicted of high and petit treason from burning to hanging, but also proposed to extend the secondary punishment of public dissection to a wider range of offenses. His bill was defeated in the House of Lords, and while the Parliamentary Debates do not provide a verbatim report of the debate, it is clear that Lord Loughborough's stance against the bill was the decisive factor in its demise. 171

Lord Loughborough devoted most of his attack to the part of the bill relating to the disposal of the bodies of criminals after execution. In particular he criticized William Wilberforce for failing to consult with the judges who would be most directly affected by this alteration in the law. ${ }^{172}$ His argument against the extension of dissection to offenses other than murder was interesting. He asserted that this provision in the criminal law "had been attended with the most salutary consequences to the moral of mankind and to the good order of the community."173 If public dissection were provided for every capital offenses, this salutary effect might be lost:

Another consideration of no small importance was the strong prejudices of all ranks of people, but especially of the lower order, in favour of burial and the disposal of their bodies after death....

167. Radzinowicz, A History 1: 210

168. Eden, Principles, 243.

169. Radzinowicz, A History 1: 321

170. U.K. Parliamentary Debates (Commons) 23 (1786), cols. 157-158.

171. U.K. Parliamentary Debates (Lords) 23 (1786), cols. 87-95. See also Radzinowicz, A History 1:
476-478. 77. $476-478$.

172. U.K. Parliamentary Debates (Lords) 23 (1786), cols. 88-89.
173. Ibid. $90-91$.
His Lordship stated the tendency that the bill would have to remove al religious prejudices from the minds of the lower order of the people. ${ }^{174}$

With respect to the proposal to change the punishment for "female traitors", Lord Loughborough's position was that the number of women executed for high treason was so small as to make the proposed change in the law unnecessary. But with respect to altering the penalty for petit treason, Lord Loughborough was unequivocal

...he was not ready to consent, as there were cases of petty treason, such as a wife's murdering her husband, and others of a like nature, of a very flagrant and atrocious cast, and which called for a more exemplary punishment than other crimes. ${ }^{175}$

The Wilberforce bill died in the House of Lords. Four years later another attempt to change the punishment for high and petit treason met with greater success.

The success of the later attempt reflected a change in public feeling about the penalty for women convicted of petit treason. Peter Linebaugh has argued that "the efficacy of public punishment depends upon a rough has argued between those who wield the law and those ruled by it." 176 Public hangings in eighteenth century England were often tumultuous affairs marked by disruptions and attempts to rescue the bodies of the executed from the hands of the dissecting surgeons. These disruptions could not go unnoticed by the
authorities.

Leon Radzinowicz has similarly argued that public feeling against the penalty of burning women was growing in the late eighteenth century. He refer to the reaction of the crowd at the execution of Christian Murphy in 178917 apparently the last woman to be executed by burning. ${ }^{178}$ Her seven confederates were hung for the same offence. The disparity in punishment provided for men and women convicted of the treasonous offence of coining seemed to be the motivating factor in the change in the law. Indeed, when the bill introduced by Sir Benjamin Hammett in 1790 was debated, scant mention was made of petit treason in the debate. The bill proceeded very quickly through the two Houses, and was assented to by the House of Lords on June $3,1790.179$ It may be that Hammett had witnessed Murphy's of Lords on June 3, 1790. ${ }^{179}$ It may be that he indicated:

174. Ibid., 91-92

175. Ibid., $93-94$

6. Peter Linebaugh, "The Tyburn Riot Against the Surgeons," in Albion's Fatal Tree, eds., Douglas 77. Radzinowicz A York: Pantheon Books, 1975), 67.

178. McAdoo, Tyburn 33 .

179. Great Britain, Journals of the House of Commons 45 (1790): 536. It had received first reading on 
that it having been his official duty to attend on the melancholy occasion of seeing the dreadful sentence put in execution, he then designed to move for leave to bring in a bill to make some alteration, but he did not choose to venture the measure till he had consulted and received the approbation of some high authorities in the law, which was not the fact. The judgment of burning alive, applied to women for certain crimes, was the savage remains of Norman policy, and disgraced our statutes, as the practice did the common law. He maintained, that the Sheriff who did not execute this sentence of burning alive, was liable to a prosecution; but he thanked heaven that there was not an Englishman to be found, whose humanity did not triumph over the severity of the sentence, and who did not choose to run the risk, rather than attend to the letter of the judgment. 180

The fact that he had sought the opinion of the judiciary may have been of some assistance to Sir Benjamin Hammett, when one recalls the 1786 debate. He indicated that it "had in fact been recommended to him to bring in such a bill, as perfectly humane and justifiable, by several of the Judges."181 He cited the disparity between the penalties prescribed by law for men and women convicted for treason and:

He desired the House to consider the influence of the husband upon the wife, and that, in many other crimes, the laws made provision for it....He desired to remind the house, that it was proved, by experience, that the shocking punishment did not prevent the crime... and all for which he contended was, that women should not receive a more dreadful sentence than the men, who might influence the women to the commission of the crime. ${ }^{182}$

Thus wives who murdered their husbands slipped through this bill on the skirt hems of women "influenced" to crime by their husbands.

Sir Benjamin Hammett's rather paternalist argument for women's right to equal treatment before the law is not without significance, given the agitation by women of the middle class for precisely that. No causal claims will, however, be advanced here, for of equal significance is the silence on the "need" for exemplary penalties for women who violated their "most sacred obligation." Even the House of Lords was hardpressed to disagree with Sir Benjamin Hammett's description of the practice of burning women who killed their husbands as a disgraceful feature of both English law and society. The sacred obligation of wives to obey their husbands may still have retained its lofty status, but it could no longer be advanced to justify a legal sanction now described as savage and barbaric.

With the abolition of the special exemplary penalty, the special category of petit treason, firmly rooted as it was in feudal social relations, could scarcely be justified in and of itself. In 1828, the Offenses Against the Person Act eliminated the old categories of relationships, and in section 2 specifically abolished petit treason. ${ }^{183}$ Thereafter, the offence of a wife killing her husband was simply petit murder, and no greater.

\section{Implications of Petit Treason for Understanding Women, Crime, and Criminal Law in Eighteenth Century England}

The criminal law in eighteenth century England, as Douglas Hay has illustrated, assumed an unprecedented importance for the British ruling class, some of whom understood that "the criminal law is as much concerned with authority as it is with property:"

For wealth does not exist outside a social context, theft is given definition only within a set of social relations and the connection between property, power and authority are close and crucial. The criminal law was critically important in maintaining bonds of obedience and deference, in legitimizing the status quo, in constantly recreating the structure of authority which arose from property and in turn protected its interests. ${ }^{184}$

The offence of petit treason existed within and reinforced social relations (not simply of property) structured by a patriarchal form of family. That the law regarded the offence with such horror and punished the offender so brutally illustrates the importance of the patriarchal family to eighteenth century English society.

The crime statistics compiled in eighteenth century England tell us much the same thing as contemporary crime statistics purport to do. In his study of women and crime in Surrey and Sussex, John Beattie noted that "a strikingly low level of criminality of women is apparent."'185 His observation with respect to inter-spousal violence is, however, important:

The family was also the scene of violence of a different kind, for the peace of the affectionate circle was all too often shattered by bitterness and conflict between husbands and wives. In this, no doubt, women were more often victims than aggressors. ${ }^{186}$

183. Offenses Against the Person Act, 1828,9 Geo. 4, c. 31.

184. Hay, "Criminal Law," 25.

186. Beattie, "Criminality," 80

186. Ibid., 102 
official statistical record is less than illuminating Petit treason is often but the with murder as one category; 187 other times it is not mentioned at all, which may mean that no convictions were recorded in the period or, perhaps more likely, that for statistical purposes petit treason was subsumed under the general category of "wilful murder."188

Even when petit treason was recorded as a separate category in some of the Select Committee's statistics, it is impossible to determine the sex of the offender or the relationship to the victim. As well, when specific reference is made to petit treason, its numerical significance is minor. For instance, the Select Committee reported a total of 37 convictions for murder in the Norfolk circuit for the period 1767-1819; there was only one entry for "murder and petit treason" in Norfolk in $1807 .{ }^{189}$ For the Home Circuit (which included the countries of Sussex and Surrey) a total of eight convictions (and eight executions) was recorded for the period 1689-1814. ${ }^{190}$ The Western Circuit reported four convictions (and four executions) for petit treason for the years 1770-1818. ${ }^{191}$

The numerical insignificance of petit treason does not mean that it was socially insignificant. The ideological significance of the law of petit treason and the ideology of gender and familial relations it enforced and reinforced are of central importance to this study. As E.P. Thompson has insisted:

There are very great problems here - for example, as legal categories of "crime" change or as the efficiency of police improves.... But even when such problems are carefully handled, we are still left with only a very limited knowledge. For the symbolic importance of violence - whether the violence of the state and the law or the violence of protest - may have no direct correlation with quantities. ${ }^{192}$ (emphasis added)

187. John Howard's statistics in Table 6 in his work on prisons in England and Wales indicate 20 convictions for "Petty Treason and Murder" in the Norfolk circuit for the period 1750-1772 Similarly, Table 7 covering the same period for the Midland circuit indicates 30 convictions fo "murder and Petty Treason." John Howard, Prisons and Lazarettos; Volume I; The State of Prisons in England and Wales (n.d.; reprint from fourth edition, Montclair N.J.: Patterson Smith

88. For instance Appendices 13 and 14 of the Report of the Select Committee of Criminal Law executed (11) for murder in Lancaster County from 1798-1818.86 men had been committed, 10 f whom had been convicted and executed 44 women had been committed, only one of whom had been convicted and executed for murder.

Howard's statistics for London and Middlesex for the years 1772-1783 indicated that 16 men and 3 women had been executed for murder. (One woman had been "burnt," in 1773): Howard, Prisons and Lazarettos, Table 10, 484 .

189. Report of the Select Committee on Criminal Law, Appendix 12, 194-225. This case must have been that of Martha Alden, who had been convicted of petit treason in the death of her husband Knapp and Baldwin, Newgate 3: 446-447.

190. Report of the Select Committee on Criminal Law, Appendices 6, 7 \& 8, 164-183. (This figure represents the sum of the cases referred to in the three appendices)

192. Thompson, "Folklore, Anthropology," 10.
The law of petit treason reveals a great deal about both the legal and social position of women in eighteenth century England. Women who killed their husbands seldom received good press; the commentary on Ann Williams in Knapp and Baldwin's Newgate Calendar contained not only their analysis of the cause of her husband's murder, but also a powerful moral lesson for both husbands and wives:

The behaviour of this fiend had long been a prelude to the diabolical crime which she committed. She was in her family turbulent and dictatorial; her husband the very reverse. His mild and quiet disposition served only to nurse her opposition and violence. He had long given way to her in all things, and she, in return, ruled him with a rod of iron.

$\cdots$

The pliancy of the more unfortunate man in question could not shield him from the consequence of the ascendancy she had over him; it sunk into contempt, and she determined to rule alone. To effect this, her wicked heart suggested the death of her husband. 193

It is difficult to sift fact from fiction in this account, given the dearth of origina data on hand to tell us more of the particulars of Ann Williams" "horrid" crime. ${ }^{19}$ Nevertheless, if the Newgate Calendar was intended for the same sort of lay audience for whom the Ordinary's Accounts and the Old Bailey Sessions Papers had been prepared, ${ }^{195}$ then even its embellished version appearing 75 years later should be of interest. The persistent portrayal in the various contemporary commentaries of women as wicked hearted fiends bent on the destruction kindly husbands reveals much about the dominant assumptions governing gender relations. The righteousness of a husband's dominance over his wife was protected not only by law.

However, even if husbands sought to assert their legal dominion over their wives (as Ann Williams' husband apparently had not done) there was no guarantee that wives would submit, as the death of John Sayer in the attempted execution of a warrant for the custody of his wife shows. The account of Amy Hutchinson's trial and execution in 1750 also contained reference to her "T.R.:"

But he being acquainted by her own mother, and others of T.R.'s frequent visits to her, grew disturbed and peevish, and several times beat her with a belt or a stick; and seeing no amendment in her, fell into

193. Knapp and Baldwin, The Newgate Calendar 2: 177-178. 194. See also Campbell, "Sentence," 46, 51-52. 
company, and drinking and by that means left her too unguarded to the wiles of her gallant, to whom she once more abandoned herself, and, at, length, by his advice she bought arsenic,. . .196

The following ballad, published not long after yet another indulgent husband, John Hayes, had been killed by his wife Catherine and her two cohorts, both satirized the affair and sermonized the audience:

In Tyburn Road, a man there liv'd, A just and honest life;

And there he might have lived still,

If it had pleased his wife.

But she to vicious ways inclin'd, A life most wicked led;

With tailors and with tinkers too, She oft defil'd his bed.

Full twice a day to church he went, And so devout would be;

Sure never was a saint on earth If that no saint was he!

This vex'd his wife unto the heart, She was of wrath so full;

That finding no hole in his coat, She pick'd one in his skull.

But then her hear 'gan to relent, And griev'd she was to sore;

That quarter to him for to give She cut him into four. ${ }^{19}$

The ballad described with generous poetic licence the events following John Hayes' death, and concluded with the admonition, "grant that we may warning take by Cath'rine Hayes' fall." The "we" referred to by the ballad's author clearly denoted other like-minded women. It is also clear that pronouncements on the character of the women and their tragic husbands were significant beyond the courtroom and their lifetimes.

\section{Conclusion}

In 1790, the practice of burning women as a penalty for some offenses was abolished. In 1828, the offence of petit treason was repealed and thereafte women who murdered their husbands stood on a formally equal footing with men who killed their wives. It is important to examine the significance of this transformation to formal equality.

The work of Michael Foucault ${ }^{198}$ suggests that the regime of punishment began to shift in the eighteenth century from torture to surveillance. The abolition of the public execution of women by burning may seem to support this assessment. Peter Linebaugh's work suggests that the agency and struggle of the public was significant, if not decisive, in the elimination of the spectacle of public execution. ${ }^{199}$ The shift from 1786 , when the first attempt to reform the law of petit treason failed, to 1790 when it met with success, may lend support to both Linebaugh and Foucault: burning women to death was no longer regarded as so rare or exceptional as to merit retention of the status quo. In 1786, William Wilberforce may not have consulted widely enough within the legal community nor may he have been able in any event to muster the necessary reservoir of support to usher through his controversial bill. Lord Loughborough's opposition was significant: petit treason was heinous but women who murdered their husbands merited the aggravated offence and penalty. The old order was thus defended in 1786, but went unacknowledged and undefended in 1790, and was simply erased in 1828

By 1828 , women accordingly had achieved formal equality with men in two respects: they had won the right to be hung, and later the right to be charged with wilful murder. It may be easy to dismiss the significance of these "victories" in the current context of feminists' weariness and disaffection with the experience of liberalism and liberal notions of equality. However, the "defeat" of petit treason represented one nail in the coffin of the old "patriarchy" and in that sense the new bourgeois order can be seen as antithetical to the patriarchal order.

While this chipping away at patriarchal relations may have illuminated the way forward for feminist engagement with law by showing that legality and equality could inhibit patriarchal relations, caution is in order here. Patriarchal relations are not of interest only to feminist archivists and archaeologists: the patriarchal family did not wither away under capitalism. Indeed, as Catherine Hall and Leonore Davidoff ${ }^{200}$ have shown, the period $1780-1830$ in England witnessed a tremendous struggle over the transformation and reformation of English society, in which the emerging middle class was significant. It involved a struggle not over the mode and means of production narrowly defined but over the hearts, minds, and lives of English society: a new mode of production to be sure, but also a new lifestyle, a new moral ethic, and new views on the family. As Catherine Hall has argued, "[t]he debate on women, the family and the sexual division of labour was. . an integral part of the 1790's discussions about the 
organisation of society." 201

The Evangelical author Thomas Gisborne implicitly acknowledged Mary Wollstonecraft's challenge to the new thinking on women's role in his Enquiry into the Duties of the Female Sex in 1798. He felt he had to respond to the arguments advanced by some that "the sphere in which women are destined is so humble and so limited, as neither to require nor reward assiduity." ${ }^{202} \mathrm{He}$ chided these women and urged them to embrace the important role they had in society:

Human happiness is on the whole much less affected by great but infrequent events, whether of prosperity or of adversity, of benefit or of injury, than by small but perpetually recurring incidents of good or evil.

The manner in which the influence of the female character is felt belongs to the latter description. It is not like the periodical inundation of a river, which overspreads once in a year a desert with transient plent. It is like the dew of heaven which descends at all seasons, returns after short intervals and permanently nourishes every herb of the field. ${ }^{203}$

The Evangelicals (among whom Thomas Gisborne and William Wilberforce were prominent) denounced the "double standard" inherent in the law of petit treason while simultaneously rejecting the equality of men and women: the "sexes are naturally distinct." 204 The construction and celebration of separate spheres with its corresponding ideology of the public and the private schism were underway even as formal equality made some gains. Ideologically and culturally, the subordination of women was now denied so that Mary Wollstonecraft's foes were both defenders of the old order and harbingers of the new. The patriarchal family was thus transformed and yet renewed, and the law of petit treason no longer signified women's subordination.

201. Catherine Hall, "The Early Formation of Victorian Domestic Ideology", in Fit Work for Women, ed. Sandra Burman (London: Croom Helm, 1979), 15, 22.

202. Thomas Gisborne, An Enquiry into the Duties of the Female Sex (London: Printed for T Caddell. Jun. and W. Davies, 1798), 11.

203. Ibid., 11-12.

204. Hall," "Victorian Domestic Ideology," 22

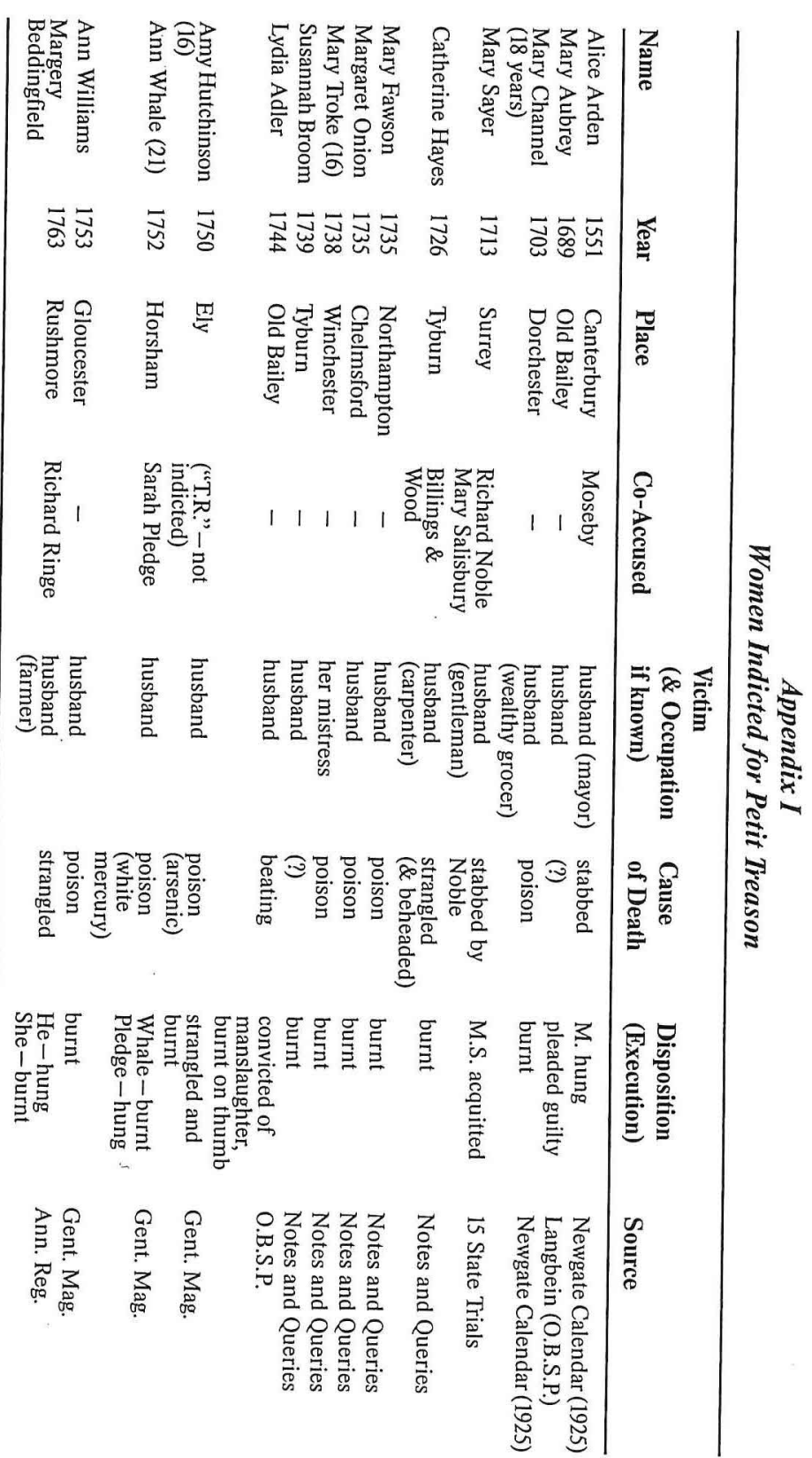




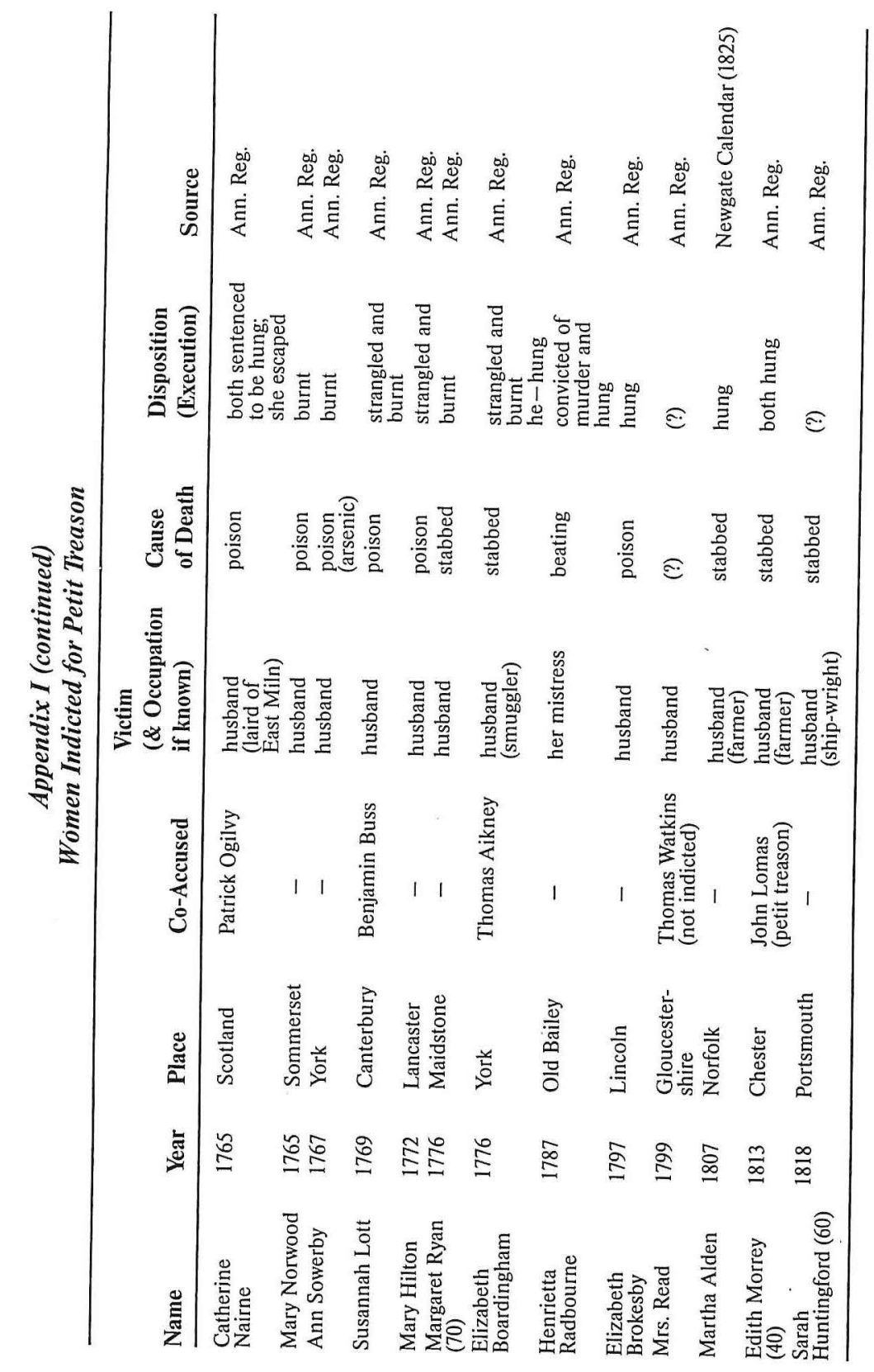

